\title{
Making a financial market: the economization and topology of Farmland REITs
}

\author{
Angela Serrano ${ }^{1}$ \\ University of Wisconsin-Madison, USA
}

\begin{abstract}
This article considers how financial mechanisms shape political and economic power around farmland. It draws on political ecology around the financialization of agriculture, and perspectives from Science and Technology Studies about performativity and topology to study how financial mechanisms in agriculture reconfigure networks of access to farmland for farmers, investors, workers and consumers. The article focuses on the case of Farmland Real Estate Investment Trusts (REITs) in the United States and shows REITS as sociotechnical assemblages of economic theories mobilized by investors and their representatives. Building on topologic ideas, the article highlights how financial mechanisms, such as REITs, shift networks of access to land. These mechanisms can profoundly shape landscapes and livelihoods by creating a market for farmland that transforms the connections of different actors with land, distancing workers and consumers from decision making processes while producing fluid and smooth access for investors. By studying REITs from the perspectives of economization and topology this article identifies key actors and mechanisms through which financialization is reconfiguring access to farmland and identifies limitations and opportunities for increased access to decisions about land for farmers, workers and consumers.
\end{abstract}

Keywords: financialization of agriculture, political ecology, performativity, topology, science and technology studies, REITs, farmland

\section{Résumé}

Cet article examine comment les mécanismes financiers façonnent le pouvoir politique et économique autour des terres agricoles. Il s'inspire de l'écologie politique autour de la financiarisation de l'agriculture et des perspectives d'études scientifiques et technologiques sur la performativité et la topologie pour étudier comment les mécanismes financiers en agriculture reconfigurent les réseaux d'accès aux terres agricoles pour les agriculteurs, les investisseurs, les travailleurs et les consommateurs. L'article se concentre sur le cas des fonds de placement immobilier agricoles (REIT) aux États-Unis et montre comme les REIT sont des ensembles sociotechniques des théories économiques mobilisées par les investisseurs et leurs représentants. En s'appuyant sur des idées topologiques, l'article souligne comment les mécanismes financiers, tels que les REIT, modifient les réseaux d'accès à la terre. Ces mécanismes peuvent profondément façonner les paysages et les moyens de subsistance en créant un marché pour les terres agricoles qui transforme les liens de différents acteurs avec la terre, éloignant les travailleurs et les consommateurs du processus de prise de décision tout en permettant aux investisseurs d'accéder facilement à la situation. En étudiant les REIT du point de vue de l'économie et de la topologie, cet article identifie les principaux acteurs et mécanismes par lesquels la financiarisation reconfigure l'accès aux terres agricoles. Il identifie également les limitations et les opportunités pour un accès accru aux décisions concernant les terres pour les agriculteurs, les travailleurs et les consommateurs.

Mots-clés: financiarisation de l'agriculture, écologie politique, performativité, topologie, études scientifiques et technologiques, REIT, terres agricoles

\section{Resumen}

El presente artículo investiga cómo los mecanismos financieros moldean el poder político y económico alrededor de la tenencia de la tierra. La investigación usa herramientas de ecología política sobre la financiarización de la agricultura, teniendo en cuenta perspectivas de estudios de ciencia y tecnología sobre

\footnotetext{
1 Angela Serrano, PhD student, Department of Sociology, University of Wisconsin-Madison, USA. Email: serranozapat "at" wisc.edu. This article was the winner of the Eric Wolf Prize, Political Ecology Society, 2018.
} 
performatividad y topología para estudiar cómo los mecanismos financieros en la agricultura reconfiguran las redes de acceso a la tierra para agricultores, inversionistas, trabajadores y consumidores. El documento se enfoca en el caso de los Fideicomisos de Inversión Inmobiliaria (REIT, por sus siglas en inglés) en Estados Unidos y muestra los REIT como conjuntos sociotécnicos de teorías económicas que son movilizados por inversionistas y sus representantes. El documento destaca la manera en que ciertos mecanismos financieros, como los REIT, pueden usarse para transformar el territorio y los medios de sustento en una región al crear un mercado de tierras que limita las relaciones de los trabajadores y los consumidores con la tierra mientras facilita oportunidades para inversionistas. La conceptualización de los REIT como conjuntos sociotécnicos proporciona información sobre los actores y discursos que sustentan dicha configuración e identifica las limitaciones y oportunidades para un mayor acceso a las decisiones sobre la tierra para agricultores, trabajadores y consumidores.

Palabras Clave: financiarización de la agricultura, ecología política, performatividad, topología, estudios de ciencia y tecnología, REIT, tierra.

\section{Introduction}

Financial investors are getting increasingly involved in agriculture. The process has drawn the attention of sociologists and geographers seeking to understand its causes and consequences. These scholars have shown that investors are attracted by the distinctive character of farmland as both a reserve of value and a factor of production, being "like gold with yield" (Fairbairn 2014: 785). The interest started around 2007, when the prices of agricultural commodities rapidly increased, and investors sought to benefit from their volatility. This process has made farm workers and small-scale farmers more vulnerable, while strengthening the position of financial investors in agriculture (Clapp 2014; Fairbairn 2014; Isakson 2014). A part of the literature on the financialization of agriculture has focused on the creation of farmland as a financial asset, drawing from relevant perspectives of Science and Technology Studies (STS) (see Li 2014; Visser 2016). STS perspectives offer a relevant view of the concrete workings and mechanisms through which financial products shape landscapes and livelihoods in agriculture. The present article builds on the literature on the financialization of agriculture with a deeper focus on STS perspectives, considering how financial products configure the farmland financial market.

To answer this question, the article draws on the case of Farmland Real Estate Investment Trusts (REITs) that are publicly traded on the stock exchange. REITs are investment companies that enjoy a special tax status. In 1960, United States legislation established REITs as trusts that can deduct dividends from their corporate tax, as long as the vast majority of their assets are in real estate and they distribute at least $90 \%$ of their income as dividends (in practice, most REITs distribute 100\% of their income as dividends, which allows them to pay no corporate tax). President Eisenhower, who signed the law containing these provisions, and other politicians and REIT representatives, cite theories about the efficiency of financial markets and the goal of making these benefits available to all Americans, to support the special tax status. For five decades, REITs were mostly focused on owning buildings in sectors such as storage, retail and lodging. Since 2013, farmland REITs trading in the stock exchange have grown, acquiring land to rent out to large farmers and agribusiness. The largest farmland REIT, Farmland Partners Inc. (FPI), started with about 7,300 acres (2,954 ha) in April 2014, and now owns over 162,000 acres ${ }^{2}$ (65,559 ha). More importantly, it plans to keep expanding, and draws on widespread perceptions of land scarcity to support expectations of future income growth (FPI 2016).

This article explores the financialization of farmland through REITs by analyzing FPI's public documents, including the 2016 Annual Report of the company, their website, and news articles. It draws on STS perspectives of economization and topology, to study the mechanisms that configure the process of financialization and explains REITS as sociotechnical assemblages of economic theories mobilized by investors and their representatives, which create a market that undermines the relations of workers and consumers with farmland while producing fluid and smooth opportunities for investors. The first two sections after the introduction present a literature review on the financialization of agriculture and STS perspectives on economization and topology. The next section describes REITs, with special attention to public farmland

\footnotetext{
2 http://www.farmlandpartners.com/properties/ accessed 20 October 2019.
} 
REITS. The article then explores the case of FPI and analyzes this case and the contribution of STS perspectives to the financialization of agriculture. The conclusion builds on the analysis of how REITs reconfigure access to land for different actors to question the rationale used by REIT interest groups for the special tax status these investment instruments hold.

\section{Finance in agriculture}

The financialization of agriculture refers to a two-way process in which financial actors are increasingly involved in agriculture, and agro-food companies place growing importance on financial gains. Finance has played a key role in agriculture for decades. What has changed over the past decade is the extent and mechanisms through which financial actors and motives are involved in agriculture (Fairbairn 2014; Isakson 2014). In this context, a growing literature has focused on identifying the features of the financialization of agriculture, as well as its effects and the reasons why it has intensified over the past years.

A tipping point for the involvement of finance in agriculture was the significant rise and volatility of food prices after 2007. This event attracted investors seeking to profit from price changes in commodities futures markets, land appreciation, and returns from yield production (Fairbairn 2014; McMichael 2012; Spratt 2013). Since then, food prices have stabilized, but the creation of mechanisms for financial investments in agriculture had lasting consequences (Clapp, Isakson and Visser 2016). Most futures contracts are now held by financial speculators, farmland equity funds have proliferated, and financial deregulation has enabled retail investors to hold shares in direct land investments (Fairbairn 2014; Spratt 2013). Land and agricultural production are attractive and increasingly available assets in financial markets.

For land and agricultural commodities to be attractive investments, they must be easily tradable. Farmland is not intrinsically a financial asset and turning it into one requires active efforts by different actors. It requires assemblage work to standardize it and make it attractive among a wide set of investors. This work includes using symbolic and material inscription devices (such as ploughs, land titles, and satellite images) that legitimate ownership of land by distant investors and exclude everyone else ( $\mathrm{Li}$ 2014). This process standardizes heterogenous tracts of land to make them tradable, and attractive for other investors. Worldwide, some of the actors who have participated in this process of assemblage include the World Bank, financial firms, and governments (Li 2014). In the United States, investment funds and the largest grain trader companies have lobbied for (de)regulations that enable them to easily buy and sell land and commodity derivatives in stock markets, and have used existing regulations in other economic sectors to expand financial ownership of farmland (Burch and Lawrence 2009; Isakson 2014; Spratt 2013). Assembling land as a financial asset has required work from governments, investors and international institutions.

It is important to note that the involvement of financial investors in agriculture is not new. What is new is the variety of available mechanisms. Until recent years, financial investors trading in public stock exchanges could only own land indirectly by buying shares of agribusiness companies that own land. Lately, the possibilities for investing in farmland, directly and indirectly, have expanded. In 2007, the New York Stock Exchange started trading agribusiness Exchange Traded Funds (ETFs), which are a financial vehicle that holds shares of different publicly traded agribusinesses and trades stock of these bundles of shares. Other forms of financial investments in land are direct purchases by institutional investors, such as pension funds, or by management organizations who buy large tracts in various places and sell shares of their bundle of properties to large investors. Their profit comes from renting out the land to agribusinesses and farmers. One of the most direct and profitable ways of trading with farmland, are farmland REITs, which became available on the New York Stock Exchange in 2013 (Fairbairn 2014; Gunnoe 2014). This text will expand on the characteristics of REITs in a later section. For now, it is important to note that they are one of the various institutional mechanisms that legitimize and enable land acquisitions by investors.

Besides explaining how the financialization of agriculture has occurred, the literature on the topic also seeks to understand why farmland has become such an attractive asset type. As mentioned before, Fairbairn (2014: 785) explains that one of the main reasons is that land is "like gold with yield", it is both a safe reserve of value and a factor of production. Additionally, land prices have a low correlation with other investments (i.e. when the price of commodities changes drastically, that of land remains relatively stable), which makes it 
attractive for investors seeking to smooth the risks of their investments. Finally, a key aspect driving investors towards farmland is its perceived scarcity, which creates expectations of price increases (Fairbairn 2014; Gunnoe 2014; Visser 2016). The material conditions of farmland, as a finite and productive object, make it attractive for financial investors.

The growing involvement of investors in agriculture can have consequences beyond the fence of any particular farm they purchase. It creates distance (both in physical and decision-making terms) between land ownership and agricultural production, increases the number of actors involved, and abstracts food from its physical form into a financial product that requires specialized knowledge. These dynamics obscure the links between practices in agriculture, and their social and ecological consequences; making political action more difficult (Clapp 2014). For instance, Isakson (2014) has identified how the increased power of financial actors deepens the vulnerability of small-scale farmers, intensifies exploitation of workers, and gives agribusiness and investors more power to influence national legislation. Additionally, because financialization facilitates the short-term operation of farms (either to ensure returns to investors or to make a short-term profit by selling it), this may lead to an unsustainable management of water and soil (Fairbairn 2014). The financialization of agriculture affects the livelihood possibilities of farmers and agricultural workers, the priorities shaping food production, the sustainability of land, and the opportunities for political action on any of these fronts.

As investors are getting more and more involved in agriculture, the literature on the topic has sought to explain the motives, mechanisms, and consequences underlying this process. The sharp rise in food prices in 2007 attracted investors to agriculture, who - with the help of governments and international organizations shaped mechanisms that facilitated their involvement beyond the period of commodity price volatility. This situation can have profound effects for the people and landscapes involved. The next section examines how land becomes a financial asset and the changes in social relations with land that this process creates.

\section{Creating markets: economization and topology}

Key authors investigating the financialization of farmland have relied on STS perspectives to understand how land is turned into a financial asset. From those referenced in the previous section, Visser (2016) and Li (2014) pay particular attention to economization, that is, how an object can become something valuable. Çalışkan and Callon (2009) see economization as a process that does not assume the economy as a pre-existing reality, but as an achievement. "The study of economization involves investigating the processes through which activities, behaviors and spheres or fields are established as being economic" (p. 370). This proposition is relevant to the financialization of farmland as it contributes to understanding how land has changed from a very local and intrinsically immobile asset, to a very liquid and easily tradable one.

From the perspective of economization, an asset is a socio-technical assemblage, a combination of cognitive and material devices. An object becomes an asset by a process in which the interested actors and the material qualities of the object conjointly construct its value. This process involves the work of different actors, some with more power than others, to re-shape the object through the inscription of knowledge and material devices that re-purpose it as an asset (Çalışkan and Callon 2009; Visser 2016). In the case of farmland, this process may involve creating discourses that portray farmland as an appreciating object that should be available to investors, and the use of capital-intensive machinery to modify it and standardize it in relation to other financialized tracts of farmland.

The actors involved use theories that conform to their interests to shape an object. The notion of performativity highlights how theories, in this case economic theories, can affect the process they seek to explain. This idea means that economics might not only describe the economy, but can also alter it (Mackenzie 2007: 55, 67). For instance, in the case of options (which are financial contracts that give the buyer the right to acquire an asset in the future at a set price) studied by Mackenzie (2007), a theory that describes how option prices behave is used by traders to make their investments, effectively shaping those prices. This theory has, in Mackenzie's words, effective performativity, which can make economic processes conform more, or less ('counter-performativity') to their depiction (Mackenzie 2007). However, the theory or depiction does not act on its own. In a critique to Mackenzie's ideas, Mirowski and Nik-Khah (2007) emphasize that economic theories are produced and used by actors with specific interests. Therefore, the types of theories used, and their 
application depends on the relations of power among people (e.g. regulatory bodies, investors and farmers). In relation to Çalışkan's work on the global cotton market, Callon explains that "it shows how dominant economic agents design and impose modalities of encountering, and consequently sociotechnical algorithms of pricing, that produce assymetries and guarantee the domination of certain agencies over others" (2007: 348). Callon goes on to explain that this case illustrates how actors involved in market transactions use economic theories and tools in their favor, and that the content and form of economic theories plays a crucial role in producing and maintaining power inequalities. Considering the performative aspect of economic theories, and the interests behind these theories can expose the importance of both knowledge and power relations in the process of economization.

At the same time, the process of asset-making involves the materiality of objects, which may impose constraints on transactions (Çalışkan and Callon 2009). Regarding farmland, it is more than obvious how despite its recently increased tradability and liquidity, it cannot be physically extracted from its place. "You cannot roll it up and take it away", in the words of $\mathrm{Li}$ (2014: 589). Within the limits imposed by the materiality of any object, the process of asset making aims to position an object in a market, which is, a larger socio-technical apparatus that makes any object-turned-asset calculable in terms of prices, and comparable to other assets (Callon and Muniesa 2005; Mackenzie 2007). In relation to the financialization of farmland, this idea does not only imply that a tract of land is standardized in relation to other tracts, but that it also becomes comparable to any other asset traded in financial markets. Economization explains the assemblage of an object into a calculable and exchangeable asset, within the material limits imposed by the object.

However, the concept of economization offers little information about how asset making affects relations in the broader configuration of the market. In regards to this configuration, Mol and Law (Law 1999; Mol and Law 1994) offer a useful discussion about the spatial forms of social relations. They suggest a topological understanding of social relations, meaning one that is open to different spatial forms and may go beyond fixed coordinates portrayed in Euclidean space. That is, beyond an understanding of space that is limited to picturing objects in three dimensions localized in fixed coordinates (Law 1999; Mol and Law 1994). Mol and Law explain that social relations are often depicted in terms of regions and networks, but they may fall into different forms in a multiplicity of spatial types. Regions characterize relations in which sets of objects can be grouped together according to a shared condition and separated by clear boundaries from other objects that do not share that condition (Mol and Law 1994: 643). Taking an example from Mol and Law's case study on the social topology of anemia, patients in different parts of the world are part of clearly differentiated regions, according to the prevalence of anemia where they live. Networks, on their part, are a spatial type in which the distance between two objects depends on the relations between them. For instance, a network depicts the relations between medical professionals in the Netherlands and Gabon that send and receive from each other a series of instruments and data to measure and record the prevalence of anemia. "However many kilometers there may be between two haemoglobin meters, in a network topology they are close to one another. Together they form a specific node in the network of measurement - a network which stretches all the way from 'needle' to 'number' via 'nurse' and 'normal distribution'" (Mol and Law 1994: 649-650). Networks are characterized by the relations between objects, rather than by any fixed condition they hold. Both the concepts of regions and networks are relevant to illustrate spatial forms of social relations, but Mol and Law make a call to consider other possibilities.

For them, thinking about these spatial forms implies abandoning fixed points, and embracing a semiotic approach, in which divisions and commonalities among entities are outcomes of their relations with one another (Law 1999: 3). This consideration opens other possibilities such as a fluid conception of social relations, one where there is "variation without boundaries and transformation without discontinuity" (Mol and Law 1994: 658). Under this understanding of social relations, there are no clear boundaries as in regions, and variation is instead a matter of degree. There are also no center or points of connection, as in networks. Instead elements in a system are connected through multiple channels. So, the relations between entities may constantly change in fluid ways. Examples of channels that connect investors to land are: contracts with tenants, the ability to decide what will be grown in a plot by only buying land that will be grown with a certain crop, or lobbying for legislation on land that is favorable to them through their trade group. In some cases, channels that connect investors to land can be so dense that they form almost fluid relations. According to Law and Mol, the idea of 
fluid relations is just one example of the different spatialities that can characterize social relations when researchers adopt semiotic analyses and are open to finding a variety of spatial forms.

\section{Making real estate and finance accessible through REITs}

According to the textbook explanation of financial markets, a financial investment is a current commitment of money in expectation of a future benefit (Bodie, Kane and Marcus 2014: 1). This type of investment is made in a financial asset, which might be just one sheet of paper or a computer entry, but the owners hold claims to the income generated by one or more real assets. Financial markets, according to this explanation, play a key role in society, as they promote a more efficient allocation of investments. They allow people to ease their consumption throughout their life, by investing in periods of high earnings and extracting the benefits in times of low earnings (Bodie et al. 2014). In this sense, the textbook Investments speaks to the reader before generalizing the experience as a benefit available for any individual: "you can "shift" your consumption over the course of your lifetime, thereby allocating your consumption to periods that provide the greatest satisfaction. Thus, financial markets allow individuals to separate decisions concerning current consumption from constraints that otherwise would be imposed by current earnings" (Bodie et al. 2014: 5-6). Apart from allowing more stable consumption through peoples' lives, financial markets make it possible to smooth risks. A financial market that offers several investment opportunities allows investors to put their money in diverse assets, with different levels of risk. They also allow the separation of ownership and management. The assets of large corporations are worth billions of dollars, so they are out of reach for most people. By trading many small parts of these assets in financial markets, the financial returns of these firms are available to more people (Bodie et al. 2014). In sum, financial markets are supposed to give people the possibility of managing their money in more efficient ways.

This theory is what justifies incentivizing investment instruments, such as REITs. President Eisenhower signed the law that created REITs in 1960. The idea was to make real estate investments available to more people and injecting more money into real estate developments. To incentivize investment in REITs, the law allowed REITs to deduct dividends from income tax, which in most cases amounts to a corporate tax exemption. In order to qualify as a REIT, a trust should own assets with at least $75 \%$ of the value coming from real estate, cash and government securities, and no more than 25\% coming from other securities; and it should distribute at least $90 \%$ of its income as dividends (Congress 1960; Krewson-Kelly and Thomas 2016). Since 1960, other laws have modified the provisions of REITs, allowing them not only to own, but also manage their properties. In 2010, the U.S. Congress celebrated the $50^{\text {th }}$ anniversary of REITs. After praising the industry, Senator Johnny Isakson from Georgia proclaimed:

Allow me to also commend our predecessors in Congress for having the foresight to enable all Americans to access and benefit from investments in real estate (...) REITs allow any investor, no matter their financial resources, to secure all of the advantages of investing in real estate in the United States. Prior to 1960, access to the highly desirable investment returns of commercial real estate assets was limited to institutions and wealthy individuals who had the financial wealth to make direct real estate investments. (Isakson 2010: 9-10)

REITs make desirable real estate investments more widely accessible. They can be private or publicly traded. In private REITs, equity is restricted to large investors, usually through private equity companies. Public REITS are traded in the stock exchange and are available to anyone who can pay the brokerage fees, when trading through an agent, or the minimum deposit for direct stock purchase (Langager 2017). According to the financial services company Bankrate, over half of Americans do not trade in stock. Of them, 53\% cite not having enough money as the main reason, and another $21 \%$ cite not having enough knowledge about stocks (Bell 2015). So, publicly traded companies may make investments more accessible, but they are still restricted for most people. 
The income of any REIT comes from renting its properties. Being exempt from corporate tax, it distributes a larger portion of its income to investors, compared to other trusts and companies. Additionally, investors and analysts generally recognize them as a safe investment with a scope of holdings likely to grow. They also have a favorable position in regards to a common concern for financial investors about their financial assets depreciating in relation to other assets or the general cost of living (Bodie et al. 2014). Real estate tends to have a lower risk in this sense, as it tends to appreciate when there is high inflation (Thomas 2012). In this context, many analysts, investors and politicians portray REITs as vehicle for everyone, including small investors, to own profitable and safe assets.

REITs are present in a variety of business areas and places. There are currently 222 public REITs, with a total market value of 1.14 trillion US dollars (NAREIT 2017b). REITs own real estate in various sectors, including retail, lodging and prisons (Krewson-kelly and Thomas 2016). NAREIT is the association representing REITs and other publicly traded real estate companies in the U.S. They produce publications about the business, compile related financial indexes, and advocate for favorable REIT legislation. When this legislation has faced threats, NAREIT has played a key role lobbying to protect it. In Hawaii, for example, legislators tried to repeal the dividends paid deduction (or tax exemption) in each year between 2014 and 2017. NAREIT testified in opposition to the proposal, and launched a campaign called The REIT Way Hawaii, which advertises the benefits of REITs for the Hawaiian economy, and their importance for the tourism and retail sectors (NAREIT 2017a, n.d.). Both the efforts to repeal the tax deduction, and the campaign defending the deduction continue (Epstein 2019). The REIT sector forms a powerful and organized group that protects its position.

In terms of farmland REITs, the first one started in 2013. Gladstone Land Corporation did its initial public offering in January that year and raised US\$50 million (Fairbairn 2014). Farmland Partners Inc (FPI) started in 2014, and American Farmland Company in 2015 (Lee 2015; PRNewswire 2017). In 2016, American Farmland Company merged with FPI, leaving only two major public REITS. Gladstone Land owns 61,000 acres (24,686 ha) of land in 9 states. FPI controls more than 162,000 acres (65,559 ha) in California, Nebraska, Georgia, and 15 other states. Both funds are growing, with several recent farm acquisitions(CNBC 2017; FPI 2017; Gladstone Land 2017). In six years, farmland REITS have become a thriving and profitable industry.

Farmland REITs have acquired land from many agribusinesses who decide to re-structure, selling the land they operate to a third party. There are two reasons commonly cited to explain this type of deal. The first one is that land, unlike buildings and most other capital assets, is not classified as depreciable by the Generally Accepted Accounting Principles (GAAP). This means that companies who own land cannot claim tax deductions on the outlay, in the years following the purchase. But if they sell the land and rent it from a third party, the rent is tax deductible (FPI 2016). Another reason for companies to re-structure in this way, is the fact that farmland values have increased steadily in the past 15 years. Agribusinesses may see this as a good opportunity to sell and raise cash to pay debts or expand. This can be particularly important for many agricultural companies that are struggling to achieve a good financial performance. Because as land values have increased, the price of agricultural commodities has decreased in the past three years (see Figures 1 and 2). So many agribusinesses face pressures from their investors to produce profits by selling land (Hickman 2007). It is important to note that this option of selling land to a REIT while still operating it, is mostly available to large agribusinesses, and not smaller farmers, as most REITs only seek to buy and rent-out large tracts of land (FPI 2016).

With rising land prices, even under decreasing crop prices, investments in farmland are very attractive. The stock of both FPI and Gladstone Land has lost value since their initial public offering. However, financial advisors still see them as reliable stocks. According to one writing for forbes.com, "given the fact that there is zero vacancies in the farming asset sector, it's virtually impossible for the farmer to switch on land so rents hold up pretty well. As a result, Farm REITs has been very stable since the first of the year, despite the turmoil" (Thomas 2016: 5-6). Farmland REITs fulfill the desire for a stable and lucrative financial asset that investors seek and offer an opportunity for agribusinesses to raise cash while maintaining the operations of their farms. 


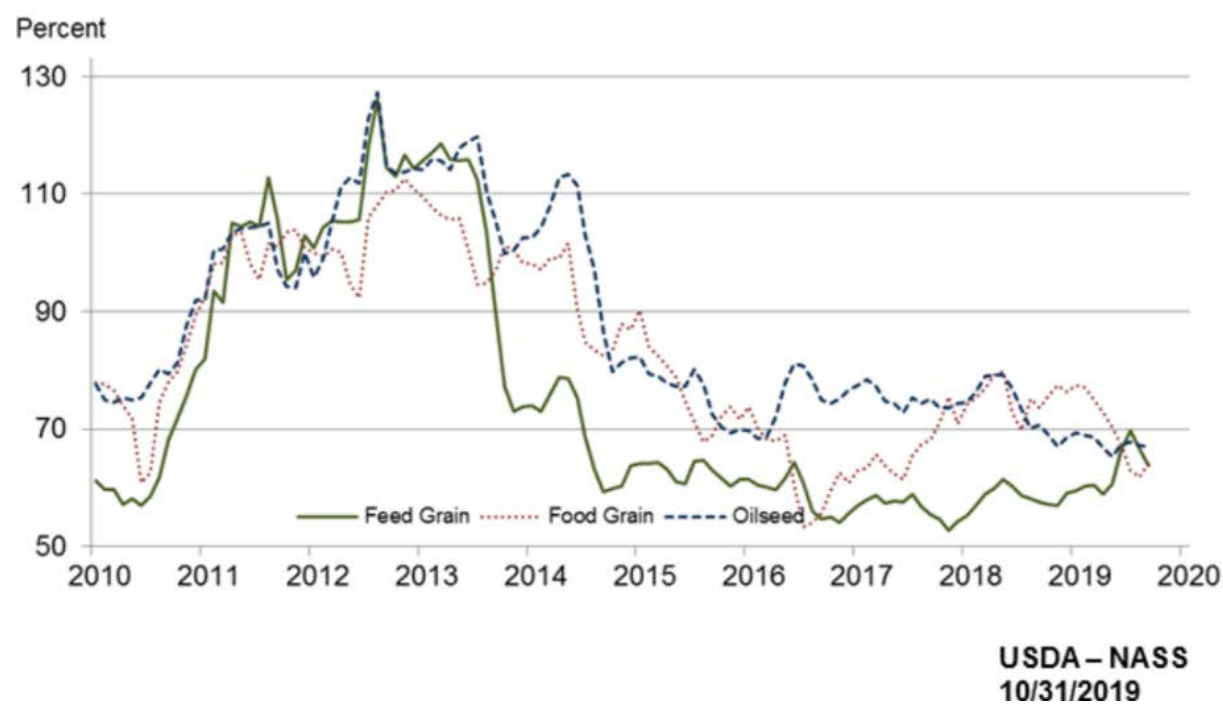

Figure 1: Agricultural, crop and livestock production price indexes - United States. Source: USDA 2019

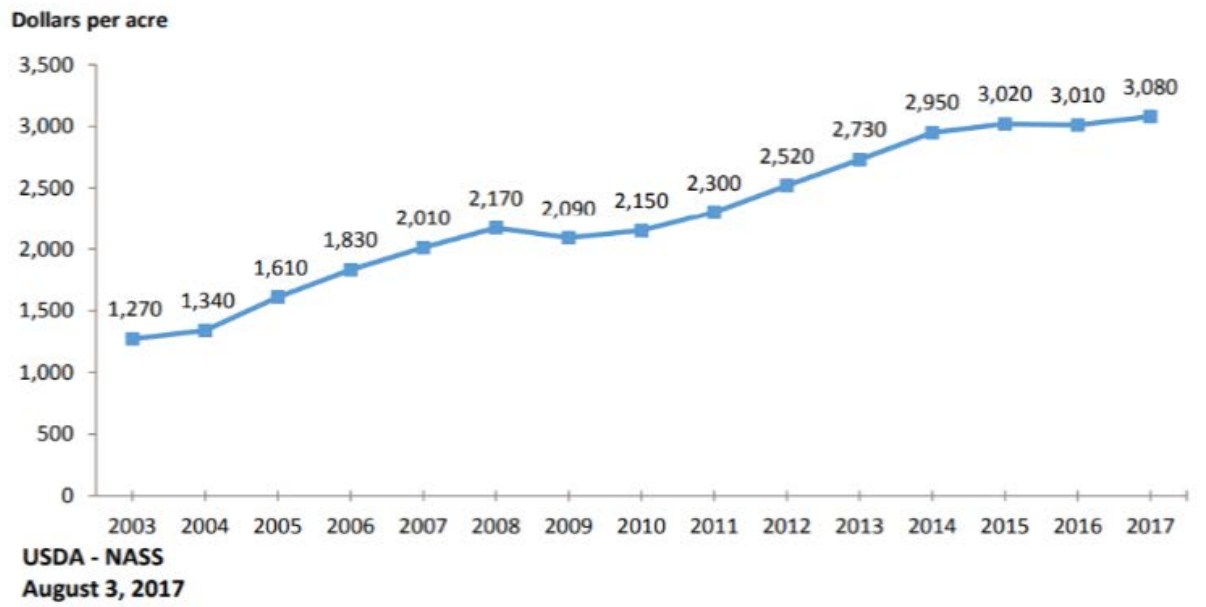

Figure 2: Average farm real estate value - United States, in US\$. Source: USDA 2017

\section{Farmland Partners Inc.}

As mentioned above, FPI did their initial public offering in 2014. Much of their discourse focuses on how much they have grown since then, how much they can still grow, and how low they can keep their costs. The first two sections of the 2016 Annual Report are "Our Vision", and "Continued Growth Story". In the first one, they explain how their portfolio provides

....a steady rental stream from farmland that appreciates in value over time as a result of the imbalance between increasing global food demand (...) and increasing scarcity of land suitable for farming. With 18 employees managing nearly US\$1.0 billion of farmland assets, and only a 
few incremental employees needed to more than double the size of our portfolio, we believe we have become the most cost efficient vehicle to invest in US farmland. (Annual Report, par. 3)

The report mentions how their portfolio has grown from 7,300 acres (2,954 ha) in 2014 to around 152,000 (61,512 ha) in 2016 (note that the previously mentioned figure of 162,000 acres is from 2019, as they have continued to acquire land after the 2016 Annual Report was released ${ }^{3}$ ). Figure 3 illustrates some of this growth:

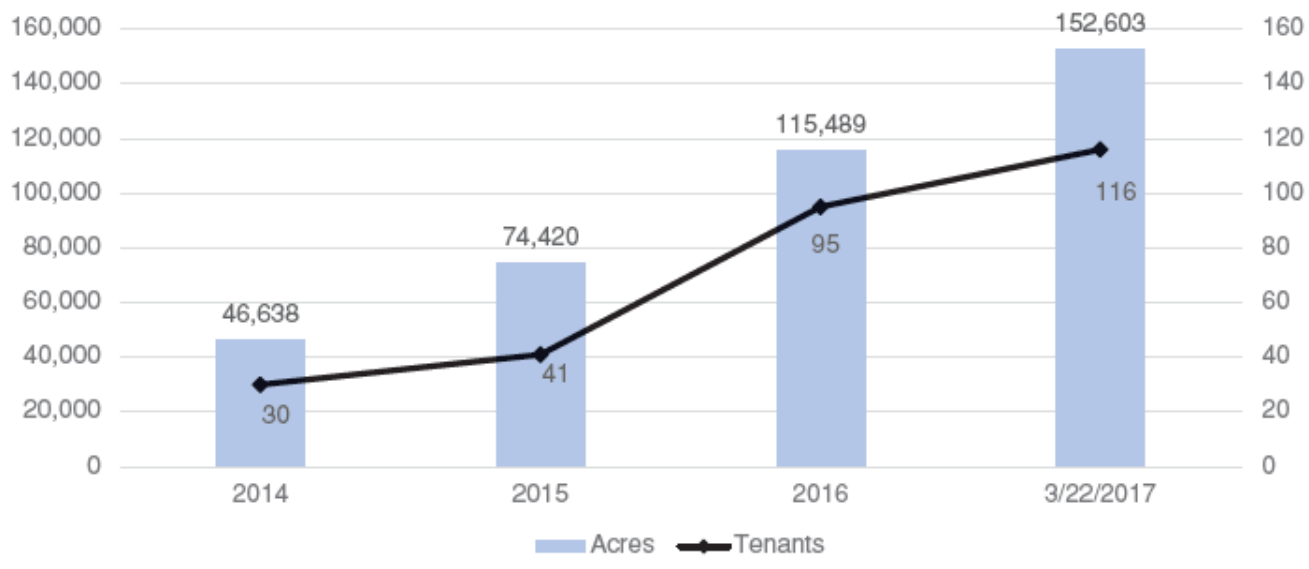

Figure 3: FPI's farmland ownership (at the end of each calendar year). 1 acre $=0.4$ ha. Source: FPI 2016

The report begins by highlighting "two truly unique transactions" (FPI 2016: 1). The first is a 22,100 acre (8,944 ha) acquisition near Paris, Illinois, for which FPI paid US\$197 million. The company asserts this has been the largest acquisition of row crop farmland in the U.S. The second one is the acquisition of all the stock of the farmland REIT American Farmland Company, which owned 17,800 acres (7,203 ha), and had an appraisal value of approximately US\$269 million (FPI 2016). A key consideration for any acquisition is the diversity of the portfolio. The current portfolio spans 18 states. It includes $75 \%$ of land devoted to primary crops (corn, wheat, cotton, etc.) and 25\% of land in specialty crops (e.g. almond, blueberries and citrus). Some of these crops are organic (FPI 2016; 2017). Expanding, while maintaining a diversity of assets, in relation to crops, regions and conventional vs. organic crops is important, because the REIT seeks to balance out risks related to losses in a specific crop, region or market.

One of the achievements of the American Farmland Company acquisition that the report highlights, is that FPI was able to absorb this company while only hiring one of their employees. To maintain low payroll costs, FPI seeks to lease out to large and scalable farms, minimizing the number of tenants they deal with. As of 2016, FPI had 100 tenants. That means that each tenant operates an average of 1,560 acres (631 ha), almost four times the average farm size in the U.S. (USDA 2016). The strategy of maintaining low costs while expanding the portfolio has allowed FPI to increase the revenue and AFFO per share (Figure 4, which shows Adjusted Funds from Operations, measures the dividend paying ability of a REIT).

\footnotetext{
${ }^{3}$ http://www.farmlandpartners.com/properties/ accessed 20 October 2019.
} 


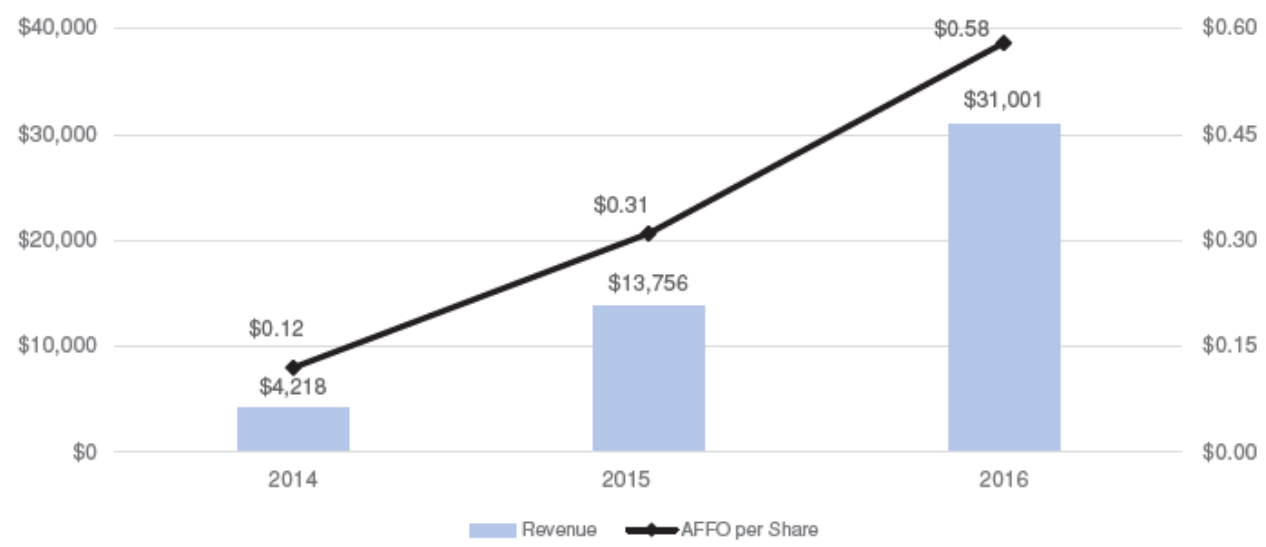

Figure 4: FPI Financial performance, US\$. Source: FPI 2016

The company communicates strong confidence in their ability to maintain or improve this performance, even in the context of low prices for agricultural commodities. Commenting for a CNBC investment guide, Paul Pittman, CEO of FPI, asserted: "the farmer still has to rent. The farmer can decide they are not buying another tractor, and the farmer can fight about rent, but can't just say, 'No, I won't rent land"' (Cited in: Gustke 2016: 19). Even under unfavorable circumstances for agricultural producers, FPI expects high demand for their farmland leases. Pittman, and other FPI executives have ample experience in management of diverse corporations. The FPI webpage shows Pittman as an experienced administrator and financier, having served in related positions at a semiconductor foundry, several investment banks, real estate companies, and one farming corporation. Similarly, the only other employee displayed on the company webpage section "About Us", Chief Financial Officer Luca Fabbri, is shown as having relevant experience in software companies, investment banking and one agricultural company (FPI n.d.). The common theme among these diverse businesses seems to be their financial goals. The 2016 FPI annual report assures stockholders that the management team's interests are aligned with theirs, as the company's executive officers and directors own a total of $6.5 \%$ of FPI's equity (FPI 2016: 6). The relevant experience and the mandates of FPI's managers center around the financial performance of the company.

The financial performance bottom line is also common for other companies with which FPI conducts business. One of their latest deals was the purchase of 5,100 acres (2,064 ha) of edible nut orchards in California for US\$110 million, from the agribusiness Olam International. Olam's strategy behind the sale is to have less assets to be able to invest and expand their operations. According to its Managing Director,

As part of our Edible Nuts strategy, we intend to further invest in growing almonds, pistachios and walnuts in California. We have built a sizable portfolio of prime orchards and have adopted sustainable and industry leading agricultural practices in managing these orchards. We had been looking for the right partner who sees the long-term value of farming, while we are looking for an asset light model to participate in the production economics of the tree crops. Farmland Partners, whose success is based on strong partnerships with farmers, is therefore a strategic fit for our business model. (Olam 2017: 4)

Olam will continue to operate the orchards for a period of 25 years, while FPI owns and receives rent for the land. Olam, like the other FPI tenants, will pay insurance and property maintenance. Other publicly available information about this deal includes that the properties are "high-quality farms in the heart of California's tree 
nut industry" and that Olam's team is composed of "exceptionally talented operators." Notably, more specific information about the land (e.g. what is "high quality") or Olam's operations (e.g. its labor relations) is absent.

FPI ensures its rents by buying land with established tenants. In the case of the Olam deal, the deal itself implied having a secured tenant for the next 25 years. This is also the case with the land acquisition in Paris, Illinois, as this farmland was already rented out to 14 tenants who signed lease agreements to continue renting the land, now from FPI. The company also signed lease agreements with four additional tenants (PR Newswire 2016). So, FPI does not buy any kind of land. It seems to target land that already offers secured rental deals.

\section{Blocks and fluids: the topology of farmland REITs}

The literature on the financialization of agriculture has identified the increasing involvement of financial actors and motives in agriculture. Companies involved in any stage of agricultural production are placing more emphasis on their financial performance, and financial investors are buying assets devoted to agricultural production. This literature has shown how changes in financial regulations, along with the beliefs and actions of governments, investors, and agri-food companies have facilitated the financialization of agriculture (Fairbairn 2014; Isakson 2014; Visser 2016). The perspective of economization provides further details about this process. It characterizes the farmland-financial-asset as a sociotechnical assemblage of cognitive and material devices, which include financial theories, legislation, computer entries linking people or companies as owners of certain shares, graphs, land, annual reports, crops, employees, indexes, etc. The theory outlined in financial textbooks and repeated by politicians (such as Eisenhower when he signed the initial REITS legislation, or the members of Congress celebrating the 50th anniversary of the law) says that financial markets, and particularly assets such as REITs, allow more people to benefit from the economic process of real estate rent and appreciation. It legitimizes the preferential tax treatment that owners of these assets enjoy. As such, the theory "describing" how financial markets are beneficial for investors has a character of effective performativity (Mackenzie 2007), as it is used to create the mechanisms that make it so beneficial. Another important cognitive device in this sociotechnical assemblage relates to the expectations of land appreciation; of farmland as an asset that, as the FPI Annual report explains, "appreciates in value over time as a result of the imbalance between increasing global food demand (...) and increasing scarcity of land suitable for farming" (FPI 2016: 3). These expectations rest on the material qualities of land as a finite resource. They mirror the preoccupations of classical economist David Ricardo, who argued that population growth necessarily results in higher land rents as more land is needed to feed a growing population. However, as Marx and others have suggested, this view ignores the possibility of producing more food from a given plot of land, through the use of technology (Fine 1979). So, it is not the relation between global food demand and land availability that produces rents for FPI. The company secures its rents by mostly buying land that already has a secured tenant. But this reasoning, as opposed to the rising global food demand discourse, does not necessarily create an expectation of continuously increasing rents, which can be crucial for attracting investors. Therefore, mobilizing a debunked, but alarming, discourse contributes to FPI's possibilities for business expansion.

This theory of land scarcity does not have such power by itself. The involvement of NAREIT in the debate about the benefits of REITs in Hawaii, and the celebration of REITs by members of Congress show that, as Mirowski and Nik-Khah (2007) suggest, theories require mobilization by interest groups to change economic processes. After all, the performativity of the beneficial aspects of REITs is only realized for potential investors (who are not the majority of the population), and not necessarily for consumers or agricultural workers (who are conspicuously absent from the discussions about these benefits). So, the business of farmland REITs becomes valuable as theories are mobilized by the interest groups that protect investors and managers' possibilities for capturing value. STS perspectives contribute to the literature on the financialization of agriculture by making evident how the special tax status of REITs is legitimized through the mobilization of economic theories by investor interest groups and politicians.

FPI's discourse also emphasizes the "high quality" of land that they have acquired. This quality includes numerous conditions that allow a crop to grow (soil, water, land elevation, etc.). However, these details are mostly absent from their analyses. REIT managers and analysts seem to take these issues for granted, presumably as standard qualities that farmland REITs consider when choosing what land to buy, and as conditions that have not deviated from their expectations (i.e. no natural disasters or unexpected soil depletion 
have occurred in the few years they have owned the land). The assemblage makes land more easily tradable, its ownership more mobile, while maintaining land in place, as its materiality makes it impossible to make it physically mobile. Ownership, after all, is the possibility to exclude others (Li 2014). In this context, it also means the possibility to make decisions about who operates land and under what conditions. Public farmland REITs, such as FPI, grant this possibility for managers, and investors, that is, people usually located far from the farmland they own. As such, the sociotechnical assemblage of public farmland REITs reconfigures the space of farmland and the relations of those who manage it, and benefit from it. REITs configure a network where farmland, and any decisions about it are far, or completely, disconnected from the people physically connected to the land, such as workers and neighbors, while being closely linked to investors who can be thousands of miles away. As Clapp (2014) mentions, this situation creates distance between those working on farmland and those who can make decisions about it, facilitates the short-term operation of farms, and affects the sustainability of land uses.

REIT managers make decisions according to the income priorities of investors, while other considerations are secondary or irrelevant. The discussions about diversity are a good example. FPI's Annual Report mentions diversity as one of their key considerations when acquiring farmland. They refer to portfolio diversity, which means that their farmland is in different regions, and has a variety of crops and qualities (e.g. organic and non-organic agriculture), to ensure that their risk of losses in one place or crop can be balanced out by earnings in others. Diversity does not refer to the identity of farmers or the varieties of crops within a farm. FPI seeks to deal with large and scalable farms, which imply few farmers growing mostly monocultures under standardized procedures. Additionally, the relevant experience of farmland REIT managers relates to financial performance, and not knowledge about the particularities of agriculture. These conditions make the benefits of REITs more available to investors, and more distant from everyone else. As a result, theories of the benefits of financial investments have effective performativity for investors and counter-performativity for workers, consumers and neighbors. These effects are made possible by the power that financial investors have (and continue to accumulate through mechanisms such as REITs) to affect legislation in their favor, and that others lack. Land becomes easily accessible for investors, while excluding the interest of workers, consumers, and many others. Those with access to the stock exchange, can buy and sell farmland with a click, while those without access to it have no possibilities. Public farmland REITs create a network for investors so dense at the financial level that it is almost fluid, while inhibiting activities of non-investors. This is particularly evident when the FPI report mentions food and land scarcity as something to celebrate in the steady rental stream for investors, rather than an issue of concern. As REITs celebrate and cultivate these conditions, they continue to accumulate opportunities at the financial level and to undermine opportunities at the ground level. The topological analysis proposed by Mol and Law (1994) provides a relevant understanding of the spatial form of the market that public farmland REITs create as fluid for investors, and blocked for everyone else.

\section{Final remarks}

The literature on the financialization of agriculture shows that the increased involvement of financial investors in agriculture can have severe consequences for the sustainability of land and the possibilities of political action by small-scale farmers, consumers, and agricultural workers. Exploring this process from the perspectives of economization and topology, proposed by STS scholars, illuminates the mechanisms that configure the process of financialization. Through the dialogue between these perspectives, the article has shown that REITS are a sociotechnical assemblage of economic theories mobilized by investors and their representatives that undermine the relations of workers and consumers with farmland while creating fluid connections for investors. REITs perform economic theories that define financial markets as efficient mechanisms for saving and diversifying risk, for the benefit of those with access to these markets. This performativity is mediated by organized politics in the form of the REIT association NAREIT and the representation of politicians such as members of the US Congress. At the same time, this performativity reconfigures networks that weaken or eliminate the relations of consumers, workers, and neighbors with land and strengthen those of investors.

Studying the financialization of agriculture from the perspective of STS provides a concrete understanding of the mechanisms and shifts in social relations that devices such as REITs configure. It illustrates the mechanisms used by REIT companies to legitimize their special tax status, through the mediation of powerful institutions, such as NAREIT, and policymakers. REITS canalize the benefits derived from tax 
deductions, discourses on land scarcity, and taking advantage of the financial pressures of agricultural companies, to REIT managers and investors. At the same time, REITs can have severe consequences for the possibilities of political action by small-scale farmers, consumers, and agricultural workers. Exploring this process from the perspectives of economization and topology illuminates the mechanisms that configure the process of financialization. As lawmakers continue to praise the benefits of REITs, frameworks from Science and Technology Studies that investigate the configuration of social and technological arrangements are crucial for political ecologists to make evident the distribution of costs and benefits that these arrangements create in relation to access to land.

Still, many questions remain. Future work should focus on the avenues that may remain open for workers and consumers to shape agriculture in the context of the financialization of farmland. Analyzing REITs through STS perspectives can contribute to understanding not only the changing financial mechanisms in a context of financialization of agriculture, but also pathways to forge more equitable access to land.

\section{Bibliography}

Bell, C. 2015. Did you miss the stock market rally? you're not alone. Retrieved December 18, 2017 https://www.bankrate.com/investing/did-you-miss-the-stock-market-rally-youre-not-alone/.

Bodie, Z., A. Kane and A. Marcus. 2014. Investments. 10th ed. New York: McGraw Hill.

Burch, D. and G. Lawrence. 2009. Towards a third food regime: behind the transformation. Agriculture and Human Values 26(4): 267-279.

Çalışkan, K. and M. Callon. 2009. Economization, part 1: shifting attention from the economy towards processes of economization. Economy and Society 38(3): 369-398.

Callon, M. 2007. What does it mean to say that economics is performative? In D. Mackenzie, F. Muniesa and L. Siu (eds.). Do economists make markets? on the performativity of economics. Princeton, NJ: Princeton University Press. Pp 310-357.

Callon, M. and F. Muniesa. 2005. Peripheral vision economic markets as calculative collective devices. Organization Studies 26(8): 1229-1250.

Clapp, J. 2014. Financialization, distance, and global food politics. The Journal of Peasant Studies 41(5): 797814.

Clapp, J., S. Ryan Isakson and O. Visser. 2016. The complex dynamics of agriculture as a financial asset: introduction to symposium. Agriculture and Human Values 34(1): 1-5.

CNBC. 2017. Gladstone land announces acquisition of organic almond orchard and expansion of metlife credit facility. Retrieved December 15, 2017 (https://www.cnbc.com/2017/12/18/globe-newswire-gladstoneland-announces-acquisition-of-organic-almond-orchard-and-expansion-of-metlife-credit-facility.html).

Congress, U.S. 1960. Public law 86-779. Washington DC: US Congress. https://www.govinfo.gov/content/pkg/STATUTE-74/pdf/STATUTE-74-Pg998.pdf\#page=4

Epstein, R. 2019. It's absurd that REIT income is not taxed in Hawaii. Honolulu Civil Beat https://www.civilbeat.org/2019/04/its-absurd-that-reit-income-is-not-taxed-in-hawaii/

Fairbairn, M. 2014. 'Like gold with yield': evolving intersections between farmland and finance. Journal of Peasant Studies 41: 1-19.

Fine, B. 1979. On Marx's theory of agricultural rent. Economy and Society 8(3): 241-278.

FPI. 2016. 2016 Annual Report to Stockholders. Retrieved November 20, 2019 http://ir.farmlandpartners.com/Cache/1001221793.PDF?O=PDF\&T=\&Y=\&D=\&FID=1001221793\&ii $\underline{d=4426904}$

FPI. 2017. Properties. Retrieved December 15, 2017 http://www.farmlandpartners.com/properties/

FPI. n.d. About us. Retrieved December 10, 2017 http://www.farmlandpartners.com/about-us/

Gladstone Land. 2017. Gladstone land acquires organic farm in Washington State for \$9.5 million. Retrieved December 15, 2017 http://ir.gladstoneland.com/releasedetail.cfm?releaseid=1039873 
Gunnoe, A. 2014. The political economy of institutional landownership: neorentier society and the financialization of land. Rural Sociology 79(4): 478-504.

Gustke, C. 2016. Farm to market: taking stock of the agricultural land grab. CNBC. Retrieved December 17, 2017 https://www.cnbc.com/2016/01/21/getting-your-plot-of-american-farmland-.html

Hickman, C. 2007. TIMOs and REITs. Retrieved December 5, 2017 https://www.fs.fed.us/cooperativeforestry/library/timo_reit.pdf

Isakson, J. 2010. 50th anniversary of real estate investment trusts. Retrieved December 15, 2017 https://www.gpo.gov/fdsys/pkg/CREC-2010-09-14/html/CREC-2010-09-14-pt1-PgS7081.htm.

Isakson, S.R. 2014. Food and finance: the financial transformation of agro-food supply chains. The Journal of Peasant Studies 41(5): 749-775.

Krewson-Kelly, S. and R. Brad Thomas. 2016. The intelligent REIT investor: how to build wealth with real estate investment trusts. Hoboken, NJ: Wiley.

Langager, C. 2017. Start investing with only \$1,000. Investopedia.

Law, J. 1999. After ANT: complexity, naming and topology. in J. Law and J. Hassard (eds.). Actor network theory and after. Malden, MA: Blackwell. Pp. 1-14.

Lee, U. Jin. 2015. American farmland (AFCO) stock plunges on first trading day. The Street. Retrieved December 18, 2017 https://www.thestreet.com/story/13330987/1/american-farmland-afco-stockplunges-on-first-trading-day.html.

Li, T.M. 2014. What is land? assembling a resource for global investment. Transactions of the Institute of British Geographers 39(4): 589-603.

Mackenzie, D. 2007. Is economics performative? Option theory and the construction of derivatives markets. In D. Mackenzie, F. Muniesa, and L. Siu (eds.). Do economists make markets? On the performativity of economics. Princeton, NJ: Princeton University Press. Pp. 54-86.

McMichael, P. 2012. The land grab and corporate food regime restructuring. Journal of Peasant Studies 39(34): 681-701.

Mirowski, P. and E. Nik-Khah. 2007. Performativity, and a problem in science studies, augmented with consideration of FCC auctions. In D. Mackenzie, F. Muniesa, and L. Siu (eds.). Do economists make markets? On the performativity of economics. Princeton, NJ: Princeton University Press. Pp. 190-224.

Mol, A. and J. Law. 1994. Regions, networks and fluids: anaemia and social topology. Social Studies of Science 24(4): 641-671.

NAREIT. 2017a. Hawaii. Retrieved Oct. 18, 2019 https://www.reit.com/nareit/advocacy/policy/state-taxissues/hawaii

NAREIT. 2017b. REIT industry financial snapshot. Retrieved December 18, 2017 https://www.reit.com/dataresearch/reit-market-data/reit-industry-financial-snapshot.

NAREIT. n.d. The REIT Way Hawaii. Retrieved December 10, 2017 http://thereitwayhawaii.com/

Olam. 2017. Olam international sells farmland assets and enters into revenue sharing model with farmland partners for its edible nuts orchards in California. Retrieved December 5, 2017

PR Newswire. 2016. Farmland partners inc. announces closing of \$197 million illinois transaction. Retrieved August 8, 2019 https://www.prnewswire.com/news-releases/farmland-partners-inc-announces-closingof-197-million-illinois-transaction-300230196.html

PR Newswire. 2017. Farmland partners inc. and American Farmland Company stockholders approve merger expected to close on February 2, 2017. Retrieved December 15, 2017 https://www.prnewswire.com/news-releases/farmland-partners-inc-and-american-farmland-companystockholders-approve-merger---expected-to-close-on-february-2-2017-300399837.html

Spratt, S. 2013. Food price volatility and financial speculation. Working Paper 047 www.futureagricultures.org. Sussex: IDS.

Thomas, R.B. 2012. Eisenhower paved the way for REIT investors to enjoy durable dividends. Forbes. Dec. 12. 
Thomas, R.B. 2016. Farmland partners growing like a weed. Forbes. April 7.

USDA. 2016. Farms and land in farms. Retrieved Oct. 15, 2019. https://www.usda.gov/nass/PUBS/TODAYRPT/fnlo0217.pdf

USDA. 2017. Land values $2017 \quad$ summary. $\quad$ Retrieved $\quad$ Oct. $15, \quad 2019$. https://www.usda.gov/nass/PUBS/TODAYRPT/land0817.pdf

USDA. 2019. "Received indexes by month." Retrieved Oct. 15,2019 https://www.nass.usda.gov/Charts_and_Maps/Agricultural_Prices/pricegr.php

Visser, O. 2016. Running out of farmland? Investment discourses, unstable land values and the sluggishness of asset making. Agriculture and Human Values 34(1): 1-14. 